ks. Wojciech Michniewicz

\title{
4. Walne Zebranie Stowarzyszenia Biblistów Polskich i 45. Sympozjum Biblistów Polskich (Pelplin, 18-20 września 2007)
}

W dniach od 18 do 20 września 2007 roku w gmachu Wyższego Seminarium Duchownego w Pelplinie odbyło się 45. Sympozjum Biblistów Polskich. Poprzedziło je wieczorne 4. Walne Zebranie Stowarzyszenia Biblistów Polskich (SBP). Uroczystego otwarcia dokonał jego przewodniczący ks. prof. dr hab. Waldemar Chrostowski. Wspomniał m.in. o aktualnym stanie osobowym stowarzyszenia, którego ilość członków wzrosła do 230 osób; przypomniał postaci niedawno zmarłych biblistów, wśród nich o. Stanisława Juliusza Synowca OFM, znanego autora szeregu przystępnych opracowań książkowych o charakterze podręcznikowym; prosił też o aktualizowanie przez członków stowarzyszenia danych personalnych i merytorycznych publikowanych w „Zeszytach Naukowych SBP”, gdyż służą one sprawniejszej komunikacji i wymianie informacji między osobami, stowarzyszeniami i różnymi środowiskami naukowymi w Polsce i za granicą. Przewodniczący podał do wiadomości zebranych również dwie ważne informacje dotyczące: $1^{\circ}$ Roku Świętego Pawła, który ma być proklamowany przez papieża Benedykta XVI 29 czerwca 2008 roku, oraz $2^{\circ}$ synodu biskupów nt. słowa Bożego w życiu i misji Kościoła, który ma się odbyć w Rzymie w październiku 2008 roku. Zachęcił w związku z tym do ukierunkowania badań biblijnych prowadzonych w nadchodzącym roku na nauczanie św. Pawła i wartość słowa Bożego jako przygotowanie i wkład biblistów polskich do tych dwu istotnych wydarzeń, które będą przeżywane we wspólnocie Kościoła powszechnego. Ks. prof. Chrostowski zapowiedział także termin i miejsce następnego spotkania biblistów na 46. sympozjum. Odbędzie się ono w dniach 16-18 września 2008 roku we Wrocławiu.

Kolejnym punktem programu było wręczenie ks. prof. dr. hab. Januszowi Frankowskiemu nagrody SBP za rok 2007. Laudację prezentującą dorobek naukowy Księdza Profesora wygłosił ks. prof. dr hab. Tadeusz Brzegowy.

Po sprawozdaniu skarbnika stowarzyszenia ks. prof. dra hab. Tomasza Jelonka dotyczącego stanu funduszy SBP za rok miniony oraz pozytywnym przyjęciu tego sprawozdania przez zebranych, przeglosowano wniosek za- 
rządu o nadanie członkostwa honorowego stowarzyszenia dwu wybitnym polskim biblistom. Otrzymali je abp prof. dr hab. Henryk Muszyński oraz bp prof. dr hab. Jan Bernard Szlaga.

Przyjęcie większością głosów regulaminu wyboru zarządu SBP zakończyło zasadniczą część obrad walnego zebrania. Przewodniczący zapowiedział, iż dołoży starań, aby wszystkie dokumenty regulujące działalność SBP zostały w najbliższym czasie wydane w formie niewielkiej broszury i przesłane wszystkim członkom stowarzyszenia.

W ramach wolnych wniosków ks. dr Piotr Ostański, autor bibliografii biblistyki polskiej za lata 1945-1999, zaapelował do zebranych o przesyłanie pełnego wykazu swej najnowszej bibliografii celem umieszczenia jej w kolejnej edycji obejmującej lata 2000-2007. Zasugerowano przy tej okazji, aby nowe edycje polskiej bibliografii biblijnej realizowane były ze względów praktycznych na nośnikach magnetycznych (płyty CD, DVD).

Pierwszy dzień obrad rozpoczął się uroczystą koncelebrowaną mszą świętą w katedrze pelplińskiej pod przewodnictwem bpa Jana Bernarda Szlagi, ordynariusza diecezji, który też w oparciu o czytania biblijne z dnia wygłosił na siedząco (czyli autorytatywnie, a zatem w zgodzie z tradycją Synagogi i Kościoła) do zgromadzonych homilię. Odniósł się w niej m.in. do współczesnych badań nad tekstem Pisma Świętego i przypomniał za Vaticanum II zasadniczy kierunek wszelkich biblijnych badań naukowych: mają one służyć „dla naszego zbawienia”. Postawił zatem zasadnicze pytania dotyczące niektórych kierunków badań: czy np. struktura semiotyczna tekstu jest nostrae salutis causa?

Po linii tych rozważań poszedł pierwszy referat wygłoszony w ramach pierwszej sesji obrad przez ks. dra hab. Stefana Szymika MSF pt. Między przeszłościa a przyszłościa. Metoda historyczno-krytyczna w badaniach biblijnych u progu XXI wieku. Prelegent przedstawił najpierw zarzuty wobec metody historyczno-krytycznej (atomizacja tekstu, różnorodność uzyskiwanych wniosków, brak odniesienia do Boga), a następnie ocenił krytycznie nowe metody badawcze, które w założeniach twórców miały być odpowiedzią na „frustrację braków metody historyczno-krytycznej”. Również one często wykazują brak chrześcijańskich podstaw filozoficznych, subiektywizm i wyraźny brak jednoznaczności. Są w jakiejś mierze odzwierciedleniem pluralizmu i liberalizmu świata zachodniego i niewiele wnoszą do badań katolickich. Chrześcijaństwo - kontynuował ks. Szymik - jest religią historyczną, którą winien cechować realizm poznawczy. Metoda historyczno-krytyczna chroni przed subiektywizmem i jakąś iluminacją, stoi na bazie Tradycji i nauczania Kościoła.

Tematyką drugiego referatu wygłoszonego przez ks. prof. dra hab. Henryka Witczyka, a zatytułowanego Jaka teologia Nowego Testamentu? była 
próba znalezienia najbardziej „holistycznej” współczesnej teologii Nowego Testamentu. Autor referatu na wstępie przedstawił historyczny rozwój nauki określanej mianem „teologia biblijna” oraz ocenił dotychczasowy pluralizm metodologiczny zauważalny w badaniach nad Nowym Testamentem. Ostatecznie podał dość „koheletowe” w swym wydźwięku stwierdzenie, że nie ma badań obiektywnych, neutralnych Biblii, że każdy podchodzi doń subiektywnie i to z własnym „przedrozumieniem” (Vorverständnis) tekstu. W dalszej części swego referatu ks. Witczyk zaprezentował cztery teologie, które jego zdaniem najbardziej zbliżają się do ideału teologii pełnej. Są to w kolejności przedstawienia: teologia kanoniczna Brevarda S. Childsa, teologia lingwistyczno-egzystencjalna Hansa Huebnera, teologia dzieła pojednania Petera Stuhlmachera oraz teologia ,anamnesis” Giuseppe Segalli. Ukazał ich plusy i minusy, najwięcej uwagi poświęcając tej ostatniej. Została ona zaprezentowana przez Segallę w 2006 roku. Jest to teologia „pamięci Jezusa”, w której przeszłość jest źródłem teraźniejszości, a nie historią minioną, struktury narracyjne tekstu (biografie, listy) są sposobem przekazywania „pamięci Jezusa” w pierwotnej wspólnocie wiary i prowadzą ostatecznie do „pamięci Kościoła”, a kanon jest sposobem strzeżenia „pamięci”. Ta teologia ma swoje trzy wymiary: historyczno-eschatologiczny (kim był, jest i będzie Jezus dla Kościoła), literacki (sposób komunikowania się z ludźmi) i kanoniczny (sens „pamięci” dla Kościoła i świata współczesnego).

Na tym zakończyła się pierwsza sesja sympozjum. Dyskusję nad zaprezentowanymi referatami z braku czasu przeniesiono na sesję drugą po przerwie na kawę i herbatę. Był to także czas na zapoznanie się z nowościami wydawniczymi w tematyce biblijnej na rynku księgarskim oraz rozmowy towarzyskie i odnowienie kontaktów w kuluarach seminaryjnej auli.

Druga sesja, której przewodniczył ks. dr hab. Dariusz Dziadosz, obejmowała referat ks. dra Marka Parchema pt. Qumran 60 lat później oraz komunikat ks. dr. hab. Mariusza Rosika zatytułowany Grecki motyw wędrówki cyklicznej w Ewangelii wedtug św. Łukasza.

Ks. Parchem po krótkim wprowadzeniu metodologicznym i zarysowaniu historii i znaczenia odkryć qumrańskich dla studiów biblijnych zreferował swój temat w trzech zasadniczych punktach. Po pierwsze przedstawił wieloaspektowość judaizmu okresu Drugiej Świątyni, w którym trzy główne haireseis (według Józefa Flawiusza), czyli faryzeusze, saduceusze i esseńczycy, stanowili tylko część bogatej, bo obejmującej ok. 20 grup (według Jamesa H. Charleswortha) mozaiki religijnej Izraela w tym czasie. Spuścizna samych esseńczyków obejmuje ok. 800 rękopisów (z tego 250 stanowią biblijne własne lub przejęte) zawierających wiele różnych teologii. Po drugie autor referatu wskazał na znaczenie zwojów qumrańskich dla lepszego zrozumienia formowania się 
tekstu biblijnego. Wnioskiem tej części przedłożenia było, iż w okresie Drugiej Świątyni funkcjonowało na terenie Izraela kilka typów tekstu hebrajskiego różnych od TM. Były to teksty qumrańskie, protomasoreckie, przedsamarytańskie, teksty zbliżone do LXX oraz pozostałe, odmienne. Wszystkie były reprezentatywne dla całego judaizmu, a nie tylko dla esseńczyków. Wreszcie po trzecie wskazał na znaczenie odkryć qumrańskich dla lepszego rozumienia tekstów Nowego Testamentu. Jakkolwiek - jak stwierdził prelegent - brakuje wzajemnych odniesień w literaturze qumrańskiej i Nowym Testamencie, to istnieją przecież paralele lingwistyczne i zbliżone formy literackie, np. w dziele Janowym. Odkrycia qumrańskie przyczyniły się do zmiany sposobu interpretowania tekstów Nowego Testamentu (widziano w nim teraz nie tylko tradycje hellenistyczne) i poczucia głębszego zakorzenienia chrześcijaństwa w kontekście judaizmu. W podsumowaniu swego referatu ks. Parchem powiedział, iż w obliczu ograniczoności naszej wiedzy o Qumran potrzeba nam więcej pokory w podejściu do tych odkryć i w interpretacji ich danych, tym bardziej że odkrycia trwają nadal (znaleziono niedawno 30 nowych tekstów).

Przedmiotem zainteresowania ks. Rosika był motyw cykliczności akcji występujący w literaturze greckiej, a zauważalny zdaniem referenta również w tekstach Ewangelii według św. Łukasza. W pojęciu cykliczności akcji chodzi przede wszystkim o takie ukazanie wydarzeń, że ich początek i koniec zbiegają się w tym samym miejscu. Autor komunikatu dostrzega tę cykliczność m.in. w schemacie: świątynia Jerozolimska - Galilea - świątynia Jerozolimska, w niektórych przypowieściach (o zaginionej owcy, o przewrotnych dzierżawcach winnicy, o synu marnotrawnym) i w innych perykopach (scena wysłania apostołów na misję, wędrówka do Emaus), a także w motywie inkarnacyjnym (zstąpienie na ziemię - wniebowstąpienie). Zasadniczym celem wprowadzenia greckiego motywu wędrówki cyklicznej do Ewangelii przez św. Łukasza było w opinii ks. Rosika ułatwienie przyjęcia Ewangelii w świecie greckim.

W dyskusji, która miała miejsce bezpośrednio po komunikacie, a objęła tematycznie obie wcześniejsze sesje, odniesiono się przede wszystkim do komunikatu ks. Rosika i referatu ks. Witczyka. Ks. prof. dr hab. Waldemar Rakocy dość sceptycznie ocenił ideę wędrówki cyklicznej jako istotnej cechy Łukaszowej Ewangelii, stwierdzając, że wszyscy nieustannie dokądś idziemy i potem wracamy do punktu wyjścia, ale „czy to jest grecki motyw cykliczności?". W dziele Łukaszowym widoczna jest bardziej myśl linearna, a zasadnicze idee związane są raczej z aspektem drogi i ludu Bożego.

Abp Muszyński podobnie sceptycznie odniósł się do teologii „pamięci” Segalli, stwierdzając, że jeden temat teologiczny to za mało, by mówić o pełnej teologii. Osobiście bardziej opowiadał się za teologią Hansa Hu- 
ebnera. W odniesieniu do motywu cykliczności u Łukasza stwierdził, że w tej Ewangelii centralnym motywem jest raczej krzyż i zmartwychwstanie.

Po zakończeniu dyskusji miała miejsce promocja księgi pamiątkowej ku czci ks. prof. Tomasza Jelonka, a po niej różne komunikaty wydawnicze. Wykonano też wspólną fotografię pamiątkową uczestników sympozjum na tle pałacu biskupiego. Czas poobiedni wypełniło zwiedzanie w grupach katedry pelplińskiej oraz muzeum diecezjalnego, w którego zbiorach znajduje się słynna dwutomowa Biblia Gutenberga (niestety, można było obejrzeć jedynie jej piękne faksymile, ponieważ dwa dni przez zjazdem biblistów oryginał został schowany w skarbcu).

Trzecia popołudniowa sesja miała charakter spotkań w czterech fakultatywnych grupach roboczych (podobnie jak rok wcześniej w Kaliszu). Pierwszą grupe poprowadził ks. dr Stanisław Jankowski, a tematem była geografia biblijna. Druga grupa pod kierunkiem ks. prof. Tomasza Jelonka zapoznawała się $\mathrm{z}$ autorskim projektem wykładu teologii biblijnej. Trzecia najliczniejsza zainteresowana była ćwiczeniami z Pisma Świętego od teorii do praktyki przedstawionymi na sposób multimedialny przez ks. dra Wojciecha Pikora. W ramach czwartej grupy prof. dr hab. Michał Wojciechowski przedstawił klasyfikację nurtów starożytnego judaizmu pod kątem relacji do kultury greckiej. Godzinne spotkania robocze zakończyły się plenarnym podsumowaniem.

Program wieczorny zgodnie z ustaloną już tradycją sympozjów biblijnych miał charakter miłego spotkania towarzyskiego służącego zadzierzgnięciu nowych i umocnieniu starych przyjaźni i kontaktów personalnych.

Drugi dzień obrad rozpoczęła uroczysta Eucharystia celebrowana tym razem przez ks. infułata dra hab. Jerzego Buksakowskiego. W kazaniu obfitującym w różne wątki tematyczne i odniesienia personalne celebrans odniósł się do szerokiego kontekstu pracy i zadań biblisty, za które to przypomnienie podziękował ks. prof. Waldemar Chrostowski, określając słowa celebransa swoistym „florilegium”.

Pierwsza sesja tego dnia, a czwarta w kolejności, której przewodniczył ks. prof. dr hab. Roman Pindel, obejmowała dwa referaty: Cherem-ostatnie stowo Starego Testamentu przedstawiony przez ks. dra Dariusza Dogondke oraz Biblia a misja pasterza w Kościele wedtug Pierwszego i Drugiego Listu do Tymoteusza oraz Listu do Tytusa zaprezentowany przez ks. dra hab. Stanisława Haręzgę. Ks. Dogondke skupił swoją uwagę na różnych kontekstach, w których pojawia się termin „cherem” w Biblii hebrajskiej, i zróżnicowanych w związku z tym tłumaczeniach tego terminu na język grecki w LXX. To sprawia, że pole semantyczne słowa „cherem” jest znacznie szersze niż w tradycyjnym rozumieniu „klątwy”, „przekleństwa”. Tak też się dzieje zdaniem prelegenta - i w Księdze Malachiasza, gdzie jest ono ostatnim 
słowem tej księgi, zarazem zamyka cały zbiór proroków, a według chrześcijańskiej tradycji układu ksiąg - jest ostatnim słowem Starego Testamentu. W tym kontekście może ono przyjmować znaczenie „całkowicie”: „abym nie przyszedł i nie poraził ziemi całkowicie [cherem]" $(3,24)$.

Z kolei ks. Haręzga, opierając się na szerokiej analizie terminów greckich dotyczących relacji przełożonego do wspólnoty oraz jego zadań wobec niej ukazanych w tzw. listach pasterskich, przedstawił rolę słowa Bożego w formowaniu pasterza i w jego posłudze na rzecz Kościoła. Jednym ze spostrzeżeń było to, że ci, którzy idą za inną, obcą nauką, nie dlatego ją wybierają, że jest lepsza, zdrowsza, lecz dlatego, że pozwala iść za własnymi pożądaniami.

Czas przeznaczony na dyskusję po obu referatach zdominowany został zasadniczo przez ks. prof. Witczyka, który w szerokim kontekście obu wypowiedzi nawiązał do Dzieła Biblijnego i jego zadań o charakterze dydaktyczno-pastoralnym.

Po przerwie odbyła się ostatnia, piąta sesja sympozjum. W jej ramach przedstawiony został jeden referat i jeden komunikat. Referat zaprezentowany przez ks. dra Janusza Kręcidłę dotyczył zastosowania techniki relektury tekstu na przykładzie J 12, 44-50. Zdaniem prelegenta wspomniany tekst znajduje się poza kontekstem Janowej Księgi Znaków i jest formą relektury Prologu (razem stanowią inkluzję dla pierwszej części Ewangelii). Został wprowadzony do tekstu na etapie ostatecznej redakcji jako wezwanie do wiary w Jezusa o charakterze uniwersalistycznym.

Natomiast komunikat ks. dra Jerzego Woźniaka ukazał postać znanego biblisty i orientalisty ks. prof. Pawła Nowickiego. Autor podkreślił wielką erudycję profesora w dziedzinie języków semickich, nadal aktualną wartość jego przemyśleń nad niektórymi zjawiskami gramatycznymi języka hebrajskiego i godną podziwu pracowitość. Ks. Woźniak podzielił się też własnymi wspomnieniami ze spotkań z księdzem profesorem z czasu swoich studiów na ATK (był bardzo lubiany i ceniony przez studentów), zwrócił uwagę na potrzebę połączenia sił „semitologów” polskich w kwestii bardziej systematycznych studiów nad językami Starożytnego Bliskiego Wschodu.

Wyznaczenie, a właściwie ponowne przypomnienie terminu i miejsca kolejnego spotkania (Wrocław, 16-18 września 2008), podziękowanie za wspaniałą gościnę i perfekcyjną organizację sympozjum włącznie z obfitą ilością starannie wydanych materiałów informacyjnych przygotowanych dla każdego uczestnika przez pelplińskich gospodarzy oraz wspólny obiad zamknęły 45. Sympozjum Biblistów Polskich. 